\title{
Nonbiliary Complications of Laparoscopic Cholecystectomy: A Single-center Experience
}

\author{
Mohit Sharma ${ }^{1}$, Rachhpal Singh ${ }^{2}$
}

\begin{abstract}
Aim: Bile duct injury is an important complication of laparoscopic cholecystectomy. Nonbiliary injuries after laparoscopic cholecystectomy can be fatal and source of considerable morbidity. In this study we intend to highlight the importance of nonbiliary complications sustained during laparoscopic cholecystectomy and their outcome.

Materials and methods: The study is analysis of patients managed in our unit with post-laparoscopic cholecystectomy nonbiliary complications from June 2010 to December 2018. Inclusion criteria—nonbiliary complications. Exclusion criteria—cases of bile duct injury, cases of surgical site infection, trocar-site hernia.

Results: A total of nine patients with nonbiliary complications were managed. Mean age of the patients was 51.1 years (range 38-65). There were five males and four females. Nonbiliary injuries were categorized into access-related and procedure-related complications. Three cases (two colonics, one inferior vena cava) were access related. Six cases (five duodenal, one ileal) were procedure related.

Conclusion: Nonbiliary injuries are of significant severity. Adequate attention in creating pneumoperitoneum and meticulous dissection helps in preventing complication. Timely detection and early therapeutic intervention can help reduce morbidity and mortality.

Keywords: Complications, Laparoscopic cholecystectomy, Nonbiliary injuries.

World Journal of Laparoscopic Surgery (2019): 10.5005/jp-journals-10033-1367
\end{abstract}

\section{INTRODUCTION}

Laparoscopic cholecystectomy is the standard of care for symptomatic cholelithiasis. The bile duct injury during laparoscopic cholecystectomy is a well-known complication. The nonbiliary injuries do occur with equally significant severity but tend to be underreported in literature. ${ }^{1}$ Nonbiliary complications can be procedure related or access related. This study describes our experience in managing nonbiliary complications after laparoscopic cholecystectomy. Various aspects like clinical presentation, severity, management and outcome has been discussed. Our study emphasis the need to prevent such complications, which are cause of significant morbidity and mortality.

\section{Materials and Methods}

This study is retrospective analysis of prospectively collected data of patients with post-laparoscopic cholecystectomy complications. The study included patients sustaining injury while operated in our hospital and also those who were operated in other hospitals and were referred to us once the injury was detected. Inclusion criterianonbiliary complications. Exclusion criteria-cases of bile duct injury, cases of surgical site infection, trocar site hernia. From June 2010 to December 2018, a total of 60 patients with post-cholecystectomy complications were managed in our unit. Of these 60 patients, 51 were of biliary tract injury and 9 were nonbiliary injuries. Nonbiliary injuries were further categorized into access-related complications, procedure-related complications. Complete record of these nine patients were reviewed. Relevant points like difficulties encountered during surgery, conversion to laparotomy (done or not), clinical presentation, timing of referral, treatment and outcome were noted.

\section{Results}

Mean age of the patients was 51.1 (38-65 years). There were five males and four females. Three cases of nonbiliary injuries occurred
1,2Department of Surgery, Sri Guru Ram Das Institute of Medical Sciences and Research, Amritsar, Punjab, India

Corresponding Author: Mohit Sharma, Department of Surgery, Sri Guru Ram Das Institute of Medical Sciences and Research, Amritsar, Punjab, India, Phone: +91 9814651788, e-mail: drmohit.gis@gmail. com

How to cite this article: Sharma M, Singh R. Nonbiliary Complications of Laparoscopic Cholecystectomy: A Single-center Experience. World J Lap Surg 2019;12(2):49-52.

Source of support: Nil

Conflict of interest: None

in our own unit (one colonic, one duodenal, one ileum), rest six cases were referred from other hospitals.

The nonbiliary complications in decreasing order of frequency were duodenal (five cases), colonic (two cases), ileal (one case), inferior vena cava (one case). Three cases (two colonics, one inferior cava) were secondary to trocar insertion. Six cases (five duodenal, one ileal) occurred during dissection.

\section{Access-related Injuries}

Colon Injury

First case was 50 years old male. He sustained injury to transverse colon during insertion of first trocar in a city nursing home. Our team was called upon as rescue surgeons. Immediate laparotomy and repair of colon injury was done. He had uneventful outcome. Second case was 44 years old female. She had h/o abdominal sepsis following open hysterectomy in the past. Transverse colon got injured during insertion of first trocar. Immediate laparotomy, repair of colonic laceration was done. She had uneventful outcome (Table 1). 
Table 1: Trocar-related injuries

\begin{tabular}{|c|c|c|c|c|c|c|c|}
\hline No. & Site of injury & Age and sex & $\begin{array}{l}\text { Presumed mechanism } \\
\text { of injury }\end{array}$ & Presentation & Interval surgery & Type of surgery & Outcome \\
\hline 1 & Transverse colon & 50 male & Direct injury-trocar & Intraoperative & Immediate & $\begin{array}{l}\text { Laparotomy, Repair } \\
\text { of perforation }\end{array}$ & Survived \\
\hline 2 & Transverse colon & 44 female & Direct injury-trocar & Intraoperative & Immediate & $\begin{array}{l}\text { Laparotomy, Repair } \\
\text { of perforation }\end{array}$ & Survived \\
\hline \multirow[t]{2}{*}{3} & Inferior vena cava & 38 male & Direct injury-trocar & Intraoperative & $\begin{array}{l}\text { Immediate by } \\
\text { primary surgeon }\end{array}$ & $\begin{array}{l}\text { Laparotomy }+ \\
\text { hemostatic suturing }\end{array}$ & Death POD10 \\
\hline & & & & & $\begin{array}{l}\text { reexploration } \\
\text { after } 24 \text { hours }\end{array}$ & & \\
\hline
\end{tabular}

Table 2: Dissection-related injuries

\begin{tabular}{|c|c|c|c|c|c|c|c|}
\hline No. & Site of injury & Age and sex & $\begin{array}{l}\text { Presumed mechanism } \\
\text { of injury }\end{array}$ & Presentation & Interval surgery & Type of surgery & Outcome \\
\hline 1 & Duodenum & 45 male & $\begin{array}{l}\text { Dissection and } \\
\text { adhesiolysis }\end{array}$ & Intraoperative & Immediate & $\begin{array}{l}\text { Duodenorrhaphy } \\
\text { with omental patch }\end{array}$ & Survived \\
\hline 2 & Duodenum & 48 male & Electrocautery & $\begin{array}{l}\text { Septicemia } \\
\text { peritonitis, duodenal } \\
\text { fistula }\end{array}$ & 10 days & $\begin{array}{l}\text { Tube duodenostomy } \\
\text { feeding jejunostomy }\end{array}$ & Death POD10 \\
\hline 3 & Duodenum & 58 female & Electrocautery & $\begin{array}{l}\text { Septic shock, perito- } \\
\text { nitis, biliary fistula }\end{array}$ & 3 days & $\begin{array}{l}\text { Duodenorrhaphy } \\
\text { with omental patch }\end{array}$ & Death POD4 \\
\hline 4 & Duodenum & 65 male & Electrocautery & $\begin{array}{l}\text { Septicemia, } \\
\text { peritonitis }\end{array}$ & 7 days & $\begin{array}{l}\text { Duodenorrhaphy } \\
\text { with omental patch }\end{array}$ & Death POD4 \\
\hline 5 & Duodenum & 57 female & $\begin{array}{l}\text { Dissection and } \\
\text { adhesiolysis }\end{array}$ & $\begin{array}{l}\text { Septic shock, biliary } \\
\text { fistula }\end{array}$ & 4 days & $\begin{array}{l}\text { Duodenorrhaphy } \\
\text { with omental patch }\end{array}$ & Death POD1 \\
\hline 6 & Ileum & 55 female & $\begin{array}{l}\text { Electrocautery } \\
\text { adhesiolysis }\end{array}$ & Peritonitis & 5 days & $\begin{array}{l}\text { Ileal resection and } \\
\text { exteriorization }\end{array}$ & Death POD10 \\
\hline
\end{tabular}

\section{Inferior Vena Cava Injury}

A 38 years old male underwent laparoscopic cholecystectomy in a peripheral rural hospital. He sustained injury to inferior vena cava during primary insertion of trocar. Immediate laparotomy and repair of injury was done by primary surgeon, however he continued to have low blood pressure despite on table repair and multiple transfusion and was referred to our hospital after 14 hours for further management. At the time of admission, he was hemodynamically unstable. After further resuscitation with blood and fresh frozen plasma he was reexplored. Preoperatively active bleeding from sutured IVC was detected, hemostatic suturing was done. However, patient continued to be in shock, disseminated intravascular coagulopathy and died on postoperative day 10 (Table 1).

\section{Dissection-related Injuries}

\section{Duodenal injury}

A total of five cases were of duodenal injury. In two cases duodenal injury was recognized intraoperatively by the primary surgeon. Of these two cases, one case was dealt with by primary surgeon with laparoscopic suturing. She developed duodenal fistula, septicemia and multiorgan failure and was referred to us with septicemia shock on day 3 . She could not survive despite resuscitation and exploratory laparotomy. In second case, our team was called for intraoperative consult. In this patient duodenal repair was done after converting to laparotomy. Patient had uneventful outcome. In another three patients, it was difficult laparoscopic cholecystectomy due to adhesions in Calot's triangle, duodenal injury was not recognized intraoperatively. All of these three patients underwent delayed repair of duodenal perforation with duodenorrhaphy and omentopexy. However, all patients succumbed to persistent septicemia and multiorgan failure (Table 1).

\section{Ileal Injury}

A 55-year-old female was taken up for laparoscopic cholecystectomy in our unit. She had past h/o laparotomy, preoperatively there were small bowel adhesions to parietal wall. Laparoscopic adhesiolysis of small bowel was done to access gallbladder, followed by laparoscopic cholecystectomy. On postoperative day 5, she developed diffuse abdominal pain, voluntary guarding and rigidity. Ultrasound abdomen revealed free fluid. Immediate exploration showed perforation of bowel from site of adhesiolysis, probably thermal injury. Resection and exteriorization of bowel was done. However patient developed multiorgan dysfunction and died on postoperative day 10 (Table 2).

\section{Discussion}

Laparoscopic cholecystectomy is the standard operation for gallstone disease. In comparison to open cholecystectomy laparoscopic approach has nearly two fold higher risk of major biliary, vascular and bowel complications. ${ }^{2}$ The approximate incidence of major bile duct injury following laparoscopic cholecystectomy is $0.4-0.86 \%{ }^{3,4}$ The incidence of major retroperitoneal vascular injury such as abdominal aorta, inferior vena cava, iliac vessels is reported to be $0.05 \% .^{5}$ The incidence of bowel injury has been reported to be between $0.06 \%$ and $0.32 \%{ }^{6,7}$

In our study we have categorized nonbiliary injuries in two categories: (1) access-related injury, (2) dissection-related injury. The insertion of first trocar in laparoscopic cholecystectomy is dangerous step with potential of bowel and vascular complication. Secondary ports being placed under vision have lower risk of complications. The faulty technique, surgeon's inexperience, forceful thrust, obesity, extreme thinness, previous abdominal surgery are the predisposing factors for access-related complications. ${ }^{8,9}$ In our case 
series we had managed three cases of access-related complications. Two colonic and one inferior vena cava. Both the colonic injuries were dealt immediately by doing laparotomy and repair of colonic laceration. There was uneventful outcome in both the cases. Inferior vena cava injury patient was a young male. He sustained injury to inferior vena cava during primary port placement in a peripheral hospital. Despite immediate laparotomy by primary surgical team and re exploration at our center, patient succumbed secondary to disseminated intravascular coagulopathy. Roviaro et al. ${ }^{10}$ in a review of literature on major vascular injuries during laparoscopic surgery has quoted high mortality rate associated with this complication. Chandler et al. ${ }^{11}$ has shown that delayed recognition of vascular injury is significantly associated with fatal outcome. Despite low incidence of vascular injuries, mortality has been reported in range of $8-17 \% .^{12}$

There are two methods of creating pneumoperitoneum for laparoscopy surgery-closed method technique, open access technique. Gaining access to peritoneal cavity is the most important step in laparoscopy, serious complications of laparoscopy surgery are related to needle or trocar insertion. ${ }^{13}$ Though rare, potentially fatal complications reported in literature in closed method technique is-vascular 0.003-1.33\%, visceral injuries $0.04-4 \% .^{14,15}$ Open access technique (Hasson) is considered to be relatively safer than closed technique. ${ }^{16}$ Optical trocar method has also shown reduction in incidence of trocar-related complications. ${ }^{17}$ Adequate manual lifting during insertion of trocar, avoiding undue thrust during insertion, insertion of secondary ports under vision, Trendelenburg position, avoiding scar of previous laparotomy are some of the methods to minimize access-related complications.

We managed six cases of dissection-related injury. Of the six cases, five were duodenal, one ileal.

The approximate incidence of duodenal injury has been reported to be $0.04 \%(0.01-0.04 \%)$ in the literature. ${ }^{18}$ Majority of duodenal injuries are as a result of dissection of gallbladder infundibulum from adherent duodenum. The sharp edge of suction device used for traction and thermal injury caused by electrocautery are some of the other important causes of duodenal injury. ${ }^{6,19,20}$ In our series of five duodenal injury cases, three cases had dense adhesions in Calot's triangle with complete obliteration of Calot's in one case. In two cases infundibulum was adherent to duodenum. In a patient with ileal perforation, probable cause was electrocautery induced thermal injury. This patient had history of laparotomy, adhesiolysis of ileal loops from parietal wall was done using electrocautery. Our series of dissection-related injuries was associated with high mortality. Only one case of duodenal injury survived, in this case duodenal injury was recognized intraoperatively and was dealt with immediate laparotomy and repair of injury. In our series of dissection-related injuries mean duration of presentation was 4.83 days (range $0-10$ days). Delayed recognition is significantly associated with mortality. Similar experience has been reported in other case series. ${ }^{21,22}$

Dissection-related injuries are more common in patients with history of repeated attacks of acute cholecystitis. Careful dissection with patience helps in avoiding injury. Early conversion to laparotomy should be considered rather than continuing in obscure field. Use of cautery should be done judiciously in Calot's triangle to minimize risk of thermal injuries. In case of uneventful recovery high index of suspicion should be maintained. Timely detection and early intervention are key to reduce morbidity and mortality.

\section{Conclusion}

Nonbiliary injuries are not uncommon after laparoscopic cholecystectomy and are of significant severity. Adherence to basic principles of laparoscopic surgery with proper attention in creating pneumoperitoneum and meticulous dissection reduces the chances of complication. Early detection followed by therapeutic intervention can help to reduce morbidity and mortality.

\section{References}

1. Rajdeep S, Robin SK, Rajeev SK, et al. Non-biliary mishaps during laparoscopic cholecystectomy. Indian J Gastroenterol 2004;23(2): 47-49.

2. Fletcher DR, Hobb MS, Tan P, et al. Complications of cholecystectomy: risks of the laparoscopic approach and protective effects of operative cholangiography: a population-based study. Ann Surg 1999;229(4):449-457. DOI: 10.1097/00000658-19990400000001.

3. Calvete J, Sabater L, Camps B, et al. Bile duct injury during laparoscopic cholecystectomy: myth or reality of the learning curve? Surg Endosc 2000;14(7):609-611. DOI: 10.1007/s004640000103.

4. Waage A, Nilsson M. latrogenic bile duct injury: a populationbased study of 152776 cholecystectomies in the Swedish Inpatient Registry. Arch Surg 2006;141(12):1207-1213. DOI: 10.1001/archsurg.141. 12.1207.

5. Deziel DJ. Complications of laparoscopic cholecystectomy: a national survey of 4,292 hospitals and an analysis of 77,604 cases. Am J Surg 1993;165(1):9-14. DOI: 10.1016/S0002-9610(05)80397-6.

6. Huang X, Feng Y, Huang Z. Complications of laparoscopic cholecystectomy in China: an analysis of 39,238 cases. Chin Med J 1997;110(9):704-706.

7. Wherry DC, Marohn MR, Malanoski MP, et al. An external audit of laparoscopic cholecystectomy in the steady state performed in medical treatment facilities of the department of defense. Ann Surg 1996;224(2):145-154. DOI: 10.1097/00000658-19960800000006.

8. Mases A, Montes A, Ramos R, et al. Injury to the abdominal aorta during laparoscopic cholecystectomy: an unusual presentation. Anesth Analog 2000;91(3):561-562. DOI: 10.1213/00000539200009000-00011.

9. Voitk A, Rizoli S. Blunt hasson trocar injury: long intra-abdominal trocar and lean patient--a dangerous combination. J Laparoendosc Adv Surg Tech A 2000;11(4):259-262. DOI: 10.1089/109264201750539817.

10. Roviaro GC, Varoli F, Saguatti L, et al. Major vascular injuries in laparoscopic surgery. Surg Endosc 2002;12(8):1192-1196. DOI: 10.1007/ s00464-001-8238-z.

11. Chandler JG, Corson SL, Way LW. Three spectra of laparoscopic entry access injuries. J Am Coll Surg 2001;192(4):478-490. DOI: 10.1016/ S1072-7515(01)00820-1.

12. Olsen DO. Laparoscopic cholecystectomy. Am J Surg 1991;16(3): 339-344. DOI: 10.1016/0002-9610(91)90592-2.

13. Hashizume M, Sugimachi K. Needle and trocar injury during laparoscopic surgery in Japan. Surg Endosc 1997;11(12):1198-1201. DOI: $10.1007 / \mathrm{s} 004649900568$.

14. Champault G, Cazacu F, Taffinder N. Serious trocar accidents in laparoscopic surgery: a French survey of 103,852 operations. Surg Endosc 1996;6(5):367-370.

15. Merlin TL, Hiller JE, Maddern GJ, et al. Systematic review of the safety and effectiveness of methods used to establish pneumoperitoneum in laparoscopic surgery. Br J Surg 2003;90(6):668-679. DOI: 10.1002/ bjs. 4203.

16. Bonjer HJ, Hazebrek EJ, Kazemier G, et al. Open versus closed establishment of pneumoperitoneum in laparoscopic surgery. Br J Surg 1997;84(5):599-602. DOI: 10.1002/bjs. 1800840506 . 
17. Catarci M, Carlini M, Gentileschi P, et al. Major and minor injuries during the creation of pneumoperitoneum: a multicenter study on 12,919 cases. Surg Endosc 2001;15(6):566-569. DOI: 10.1007/ s004640000381.

18. Testini M, Piccini G, Lissidini G, et al. Management of descending duodenal injuries secondary to laparoscopic cholecystectomy. Dig Surg 2008;25(1):12-15. DOI: 10.1159/000114196.

19. Croce E, Golia M, Russo R, et al. Duodenal perforations after laparoscopic cholecystectomy. Surg Endosc 1999;13(5):523-525. DOI: $10.1007 / \mathrm{s} 004649901027$.
20. Berry SM, Ose KJ, Bell RH, et al. Thermal injury of the posterior duodenum during laparoscopic cholecystectomy. Surg Endosc 1994;8(3):197-220. DOI: 10.1007/BF00591829.

21. Machado N. Duodenal injury post laparoscopic cholecystectomy: incidence, mechanism, management outcome. World J Gastrointest Surg 2016;8(4):335-344. DOI: 10.4240/wjgs.v8. i4.335.

22. El-Banna M, Abdel-Atty M, El-Meteini $M$, et al. Management of laparoscopic-related bowel injuries. Surg Endosc 2000;14(9):779-782. DOI: $10.1007 / \mathrm{s} 004640000015$ 